\title{
Knowledge Attitude and Practices (KAPs) on Control of Bovine African Trypanosomosis in Pastoral Communities Surrounding Murchison Falls National Park, Uganda
}

\section{Daniel Kizza ( $\nabla$ danielkizza8@gmail.com )}

Makerere University College of Veterinary Medicine, Animal Resources and Biosecurity https://orcid.org/0000-0001-6446-2894

Michaeal Ocaido

Makerere University College of Veterinary Medicine Animal resources and Biosecurity Anthony Mugisha

Makerere University College of Veterinary Medicine Animal resources and Biosecurity

\section{Sarah Nalule}

Makerere University College of Veterinary Medicine Animal resources and Biosecurity

Howard Onyuth

Makerere University College of Veterinary Medicine Animal resources and Biosecurity

Simon Peter Musinguzi

Kabale University

\section{Charles Waiswa}

Makerere University College of Veterinary Medicine Animal Resources and Biosecurity

\section{Research}

Keywords: Bovine Trypanosomosis, Murchison Falls, Knowledge, Practices, Attitudes

Posted Date: September 23rd, 2020

DOI: https://doi.org/10.21203/rs.3.rs-80628/v1

License: (c) (1) This work is licensed under a Creative Commons Attribution 4.0 International License. Read Full License 


\section{Abstract}

Background: A survey was done among pastoral communities surrounding Murchison Falls National Park, Uganda to assess knowledge, attitude and practices about the control of bovine traypanosomosis.

Methods: This was done using participatory methods and structured questionnaire.

Results: The majority of the participants had ever seen tsetse flies and had ever heard about trypanosomosis with no significant difference $(P>0.05)$ across the five sub counties About 116 participants (73.9\%) stated that trypanosomosis was a major disease in their area and across the five sub counties significant difference $(P<0.05)$ was observed. Farmers grazing near national parks and animals sharing grazing land and watering points with wild life respectively were considered the main causes of Bovine trypanosomosis. A significant difference $(P<0.01)$ in knowledge of farmers about the causes and signs of trypanosomosis in the study sub counties was observed. There was a high significant difference $(P<0.01)$ in control practices of trypanosomosis used in the study sub counties with the majority of farmers $(58.6 \%)$ using insecticide treated cattle and significantly differed across the sub counties.

Conclusion: The majority of participants had ever heard/seen tsetse flies and had ever heard about Nagana. Grazing near national parks and animal sharing grazing land and watering points with wildlife were the main causes of trypanosomosis. Insecticide treated cattle and not grazing in areas infested with tsetse flies were the major control practices of trypanosomosis. Knowledge about the disease, farmers' attitude and control practices have overtime contributed to the pastoral communities and their cattle developing the needed resilience for survival in this high risk area.

\section{Background}

Animal trypanosomosis are a major limitation for livestock production and a constraint to food security and livelihood contributing to huge economic losses to livestock industry by causing mortality of livestock, reduction in milk and weight gain, high control and treatment costs (Cox et al., 2010). Areas with high tsetse flies' presence and animal trypanosomosis prevalence limits the use of land for livestock production with farmers often reliant on only crop production. In addition, the disease affects crop production due to reduced traction power and production of manure as fertilizers (Kristjanson et al., 1999).

In sub Saharan Africa, it is projected that USD 4.75 billion is lost annually due to trypanosomosis (Van den Bossche et al., 2010).

Uganda has been one of the worst hit countries in Sub Saharan Africa with African trypanosomes accounting for over 50\% of reported T.b rhodesiense cases between 2000 and 2009 (Holt et al., 2016). According to Coordinating Office for Control of Trypanosomiasis in Uganda (COCTTU) about $70 \%$ of the whole country is estimated to be infested with tsetse flies (Albert et al., 2015). The 'tsetse belt' stretches 
from the highlands in South-western Uganda across Lake Kyoga through to north eastern Uganda. Areas around Murchison Falls National park occupied by pastoral communities are heavily infested by tsetse flies hence having high prevalence of trypanosomosis among their livestock. However controlling of bovine trypanosomiasis in this area has remained a challenge. It is against this back ground that this study was designed to understand cattle owners' attitudes, perceptions and practices in control of bovine trypanosomosis. This is critical in that locally sustainable adapted control program can be designed for this area. (Mwaseba \& Kigoda, 2017a) (WHO, 2008), (Malulu et al., 2017).

\section{Methods}

\section{Study area and population-}

\section{MAP OF UGANDA SHOWING THE STUDY DISTRICT}

The study was conducted in Buliisa district located at (02 11 N 3124 E) neighbouring Murchison Falls National Park. Buliisa was purposively selected as it is located in the cattle corridor and its proximity to Murchision Falls National Park.

\section{Study design and sampling-}

A cross sectional survey was conducted from January 2020 to April 2020 using a pre tested questionnaire. Data was collected from 157 participants that were purposively selected. The selection criteria of study participants were being a cattle farmer. Through the regional tsetse control focal person, Bullisa district production office (DPO) and veterinary office (DVO) were approached and study objectives explained. The DVO contacted the sub county animal husbandry officers (AHO) who identified the study participants. The study objectives were explained to AHO's and trained as research assistants. The questionnaire was pre tested and additional information generated and some questions were modified. The questionnaire was translated from English into Runyoro by Makerere University Center for languages and communication services (CLCS).

Based on the estimated prevalence of $41 \%$ trypanosomiasis in Nwoya, (Angwech et al., 2015) a sample size of 157 was computed using the following formula

$$
n=\frac{(Z)^{2} p q}{e^{2}}
$$

Where $\mathrm{n}=$ sample size, $\mathrm{Z}=\mathrm{Z}$ value at $95 \%$ confidence level, $\mathrm{e}=$ desired level of precision $(8 \%), \mathrm{p}=$ estimated proportion of an attribute that is present in the population, $q=100-p$

For precision 12 additional questionnaires were added to 145 calculated sample size adjusted to 157 study participants. Additional qualitative information was collected through two participatory methods; focus group discussion and key informant interviews using a check list of questions. Two focus group 
discussion were organized composed of cattle farmers while three in-depth interviews with purposively selected key informants were conducted. The discussions and interviews collected information about factors that contribute to the emergency of trypanosomosis, the livestock species affected, the age and breed of livestock most susceptible, the clinical signs livestock exhibit; drugs used and at what dose, control practices used at the farms and if they were human cases of trypanosomosis. Qualitative Information from both focus group discussion and interviews was interpreted coded and organized into themes and patterns

Data Management- Data was collected and collated from the questionnaire and observational check list. Data was then coded and entered into Excel and exported to SPPS software (IBM version 20). Descriptive statistics were generated and Chi- square test was used to identify the most significant factors associated with KAPs on controlling bovine trypanosomosis.

\section{Results}

\section{Socio-demographic characteristics of participants.}


Table 1

Socio-demographic characteristics of participants

\begin{tabular}{|c|c|c|c|c|c|c|c|}
\hline \multirow[t]{2}{*}{ Variables } & \multicolumn{5}{|c|}{ Sub counties } & \multirow[t]{2}{*}{ Overall } & \multirow{2}{*}{$\begin{array}{l}X^{2} \\
\text { Value (P } \\
\text { value) }\end{array}$} \\
\hline & $\begin{array}{l}\text { Biiso ( } n \\
=22)\end{array}$ & $\begin{array}{l}\text { Buliisa } \\
(n=51)\end{array}$ & $\begin{array}{l}\text { Butiaba } \\
(n=26)\end{array}$ & $\begin{array}{l}\text { Kigwera } \\
(n=29)\end{array}$ & $\begin{array}{l}\text { Ngwedo } \\
(n=29)\end{array}$ & & \\
\hline \multicolumn{8}{|l|}{ Gender } \\
\hline Female & 27.3 & 5.9 & 15.4 & 0.0 & 6.9 & 9.6 & \multirow[t]{2}{*}{0.011} \\
\hline Male & 72.7 & 94.1 & 84.6 & 100 & 93.1 & 90.4 & \\
\hline \multicolumn{8}{|l|}{$\begin{array}{l}\text { Education } \\
\text { level }\end{array}$} \\
\hline Primary & 36.4 & 56.9 & 42.3 & 41.4 & 62.1 & 49.7 & \multirow[t]{5}{*}{0.294} \\
\hline O-level & 40.9 & 23.5 & 34.6 & 31 & 20.7 & 28.7 & \\
\hline A-level & 9.1 & 3.9 & 15.4 & 20.7 & 3.4 & 9.6 & \\
\hline Tertiary & 9.1 & 5.9 & 7.7 & 6.9 & 6.9 & 7 & \\
\hline Illiterate & 4.5 & 9.8 & 0.0 & 0.0 & 6.9 & 5.1 & \\
\hline \multicolumn{8}{|l|}{ Land tenure } \\
\hline Customary & 4.5 & 3.9 & 57.7 & 0.0 & 58.6 & 22.3 & \multirow[t]{6}{*}{$<0.001$} \\
\hline Rented & 13.6 & 2.0 & 3.8 & 0.0 & 3.4 & 3.8 & \\
\hline Leased & 9.1 & 2.0 & 3.8 & 0.0 & 0.0 & 2.5 & \\
\hline Private/bought & 13.6 & 0.0 & 3.8 & 0.0 & 37.9 & 9.6 & \\
\hline Institutional & 13.6 & 0.0 & 3.8 & 3.4 & 0.0 & 3.2 & \\
\hline Communal & 45.5 & 92.2 & 26.9 & 96.6 & 0.0 & 58.6 & \\
\hline \multicolumn{8}{|l|}{$\begin{array}{l}\text { Record } \\
\text { keeping }\end{array}$} \\
\hline No & 77.3 & 68.6 & 61.5 & 24.1 & 44.8 & 56.1 & \multirow[t]{2}{*}{$<0.001$} \\
\hline Yes & 22.7 & 31.4 & 38.5 & 75.9 & 55.2 & 43.9 & \\
\hline
\end{tabular}

Communities' awareness and perception (attitude) about tsetse and bovine trypanosomosis 
Details of communities' awareness and perception (attitude) about tsetse and bovine trypanosomosis are shown in Table 2

Table 2

Participants' Awareness and perception about tsetse and bovine trypanosomosis

\begin{tabular}{|c|c|c|c|c|c|c|c|}
\hline Variables & Sub c & unties & & & & & $\begin{array}{l}x^{2} \\
\text { value } \\
(P \\
\text { value })\end{array}$ \\
\hline $\begin{array}{l}\text { Have you ever seen/heard } \\
\text { of tsetse }\end{array}$ & $\begin{array}{l}\text { Biiso } \\
(n= \\
22)\end{array}$ & $\begin{array}{l}\text { Buliisa } \\
(n= \\
51)\end{array}$ & $\begin{array}{l}\text { Butiaba } \\
(n=26)\end{array}$ & $\begin{array}{l}\text { Kigwera } \\
(n=29)\end{array}$ & $\begin{array}{l}\text { Ngwedo } \\
(n=29)\end{array}$ & $\begin{array}{l}\text { Overall } \\
(\mathrm{N}= \\
157)\end{array}$ & \\
\hline Yes & 100 & 98 & 92.3 & 96.6 & 96.6 & 96.8 & 0.610 \\
\hline No & 0 & 2 & 7.7 & 3.4 & 3.4 & 3.2 & \\
\hline \multicolumn{8}{|l|}{$\begin{array}{l}\text { Cattle disease transmitted } \\
\text { by tsetse }\end{array}$} \\
\hline I don't know & 0 & 13.7 & 11.5 & 3.4 & 3.4 & 7.6 & 0.165 \\
\hline Nagana & 100 & 86.3 & 88.5 & 96.6 & 96.6 & 92.4 & \\
\hline \multicolumn{8}{|l|}{$\begin{array}{l}\text { Human disease } \\
\text { transmitted by tsetse }\end{array}$} \\
\hline I don't know & 9.1 & 25.5 & 19.2 & 44.8 & 24.1 & 25.5 & 0.052 \\
\hline Sleeping sickness & 90.9 & 74.5 & 80.8 & 55.2 & 75.9 & 74.5 & \\
\hline \multicolumn{8}{|l|}{$\begin{array}{l}\text { Have you ever heard about } \\
\text { Nagana }\end{array}$} \\
\hline Yes & 90.9 & 92.2 & 88.5 & 89.7 & 96.6 & 91.7 & 0.836 \\
\hline No & 9.1 & 7.8 & 11.5 & 10.3 & 3.4 & 8.3 & \\
\hline \multicolumn{8}{|l|}{$\begin{array}{l}\text { Is Nagana a major } \\
\text { livestock disease? }\end{array}$} \\
\hline No & 18.2 & 9.8 & 19.2 & 72.4 & 20.7 & 26.1 & $<0.001$ \\
\hline Yes & 81.8 & 90.2 & 80.8 & 27.6 & 79.3 & 73.9 & \\
\hline
\end{tabular}

Communities' knowledge about causes of Bovine Trypanosomosis

Communities' knowledge about causes of Bovine trypanosomosis were presented in Table 3 
Table 3

Communities knowledge on the causes of bovine trypanosomosis

\begin{tabular}{|c|c|c|c|c|c|c|c|}
\hline Variable & Sub c & unties & & & & & $\begin{array}{l}x^{2} \\
\text { value } \\
\text { (P } \\
\text { value) }\end{array}$ \\
\hline Cause of Trypanosomosis & $\begin{array}{l}\text { Biiso } \\
(n= \\
22)\end{array}$ & $\begin{array}{l}\text { Buliisa } \\
(\mathrm{n}= \\
51)\end{array}$ & $\begin{array}{l}\text { Butiaba } \\
(n=26)\end{array}$ & $\begin{array}{l}\text { Kigwera } \\
(n=29)\end{array}$ & $\begin{array}{l}\text { Ngwedo } \\
(n=29)\end{array}$ & $\begin{array}{l}\text { Overall } \\
(\mathrm{N}= \\
157)\end{array}$ & \\
\hline $\begin{array}{l}\text { Grazing near the national } \\
\text { park }\end{array}$ & 59.1 & 58.8 & 57.7 & 48.3 & 79.3 & 60.5 & $0.004^{\star x}$ \\
\hline Not controlling the vector & 4.5 & 2 & 15.4 & 24.1 & 17.2 & 11.5 & \\
\hline $\begin{array}{l}\text { Sharing grazing land and } \\
\text { watering points with } \\
\text { wildlife }\end{array}$ & 36.4 & 21.6 & 15.4 & 20.7 & 3.4 & 19.1 & \\
\hline Grazing in infested area & 0 & 17.6 & 11.5 & 3.4 & 0 & 8.3 & \\
\hline $\begin{array}{l}\text { Trypano susceptible } \\
\text { breeds of cattle }\end{array}$ & 0 & 0 & 0 & 3.4 & 0 & 0.6 & \\
\hline
\end{tabular}

Communities' knowledge about transmission of Bovine Trypanosomosis

Knowledge about transmission of bovine trypanosomosis is presented in Table 4 
Table 4

Communities' knowledge about transmission of Bovine Trypanosomosis

\begin{tabular}{|c|c|c|c|c|c|c|c|}
\hline Variable & Sub cc & unties & & & & & \\
\hline $\begin{array}{l}\text { Transmission of } \\
\text { Trypanosomosis }\end{array}$ & $\begin{array}{l}\text { Biiso } \\
(n= \\
22)\end{array}$ & $\begin{array}{l}\text { Buliisa } \\
(n= \\
51)\end{array}$ & $\begin{array}{l}\text { Butiaba } \\
(n=26)\end{array}$ & $\begin{array}{l}\text { Kigwera } \\
(n=29)\end{array}$ & $\begin{array}{l}\text { Ngwedo } \\
(n=29)\end{array}$ & $\begin{array}{l}\text { Overall } \\
(\mathrm{N}= \\
157)\end{array}$ & \\
\hline Cattle fed on by tsetse flies & 22.7 & 21.6 & 19.2 & 44.8 & 51.7 & 31.2 & $0.003^{\star *}$ \\
\hline $\begin{array}{l}\text { Cattle fed on by tsetse with } \\
\text { disease pathogens }\end{array}$ & 40.9 & 41.2 & 19.2 & 6.9 & 34.5 & 29.9 & \\
\hline $\begin{array}{l}\text { Failure of cattle immune } \\
\text { system }\end{array}$ & 9.1 & 9.8 & 7.7 & 13.8 & 0 & 8.3 & \\
\hline Grazing in infested area & 27.3 & 27.5 & 53.8 & 34.5 & 13.8 & 30.6 & \\
\hline
\end{tabular}

Communities' knowledge about signs and symptoms of Bovine Trypanosomosis

Communities' knowledge about signs and symptoms of Bovine trypanosomosis were presented in Table 5 
Table 5

Communities' knowledge about signs and symptoms of Bovine Trypanosomosis

\begin{tabular}{|c|c|c|c|c|c|c|c|}
\hline \multirow{2}{*}{$\begin{array}{l}\text { Variable } \\
\text { Signs of trypanosomosis }\end{array}$} & \multicolumn{6}{|c|}{ Sub counties } & \multirow{2}{*}{$\begin{array}{l}x^{2} \text { value } \\
(P \\
\text { value })\end{array}$} \\
\hline & $\begin{array}{l}\text { Biiso } \\
(n= \\
22)\end{array}$ & $\begin{array}{l}\text { Buliisa } \\
(\mathrm{n}= \\
51)\end{array}$ & $\begin{array}{l}\text { Butiaba } \\
(n=26)\end{array}$ & $\begin{array}{l}\text { Kigwera } \\
(n=29)\end{array}$ & $\begin{array}{l}\text { Ngwedo } \\
(n=29)\end{array}$ & $\begin{array}{l}\text { Overall } \\
(\mathrm{N}= \\
157)\end{array}$ & \\
\hline $\begin{array}{l}\text { Emaciation / loss of } \\
\text { body weight }\end{array}$ & 9.1 & 11.8 & 57.7 & 37.9 & 62.1 & 33.1 & $<.001^{\star *}$ \\
\hline Intermittent fevers & 81.8 & 15.7 & 11.5 & 17.2 & 6.9 & 22.9 & \\
\hline Rough coat & 4.5 & 52.9 & 15.4 & 31.0 & 27.6 & 31.2 & \\
\hline Diarrhea & 4.5 & 19.6 & 3.8 & 3.4 & 3.4 & 8.9 & \\
\hline Anemia & 0 & 0 & 11.5 & 3.4 & 0 & 2.5 & \\
\hline Circling movement & 0 & 0 & 0 & 6.9 & 0 & 1.3 & \\
\hline
\end{tabular}

Communities' practices on control and treatment of Bovine Trypanosomosis (Tables 6 and 7) 
Table 6

Communities Control Practices of Bovine trypanosomosis

\begin{tabular}{|c|c|c|c|c|c|c|c|}
\hline Variable & Sub c & unties & & & & & \\
\hline Control practices & $\begin{array}{l}\text { Biiso } \\
(n= \\
22)\end{array}$ & $\begin{array}{l}\text { Buliisa } \\
(n= \\
51)\end{array}$ & $\begin{array}{l}\text { Butiaba } \\
(n=26)\end{array}$ & $\begin{array}{l}\text { Kigwera } \\
(n=29)\end{array}$ & $\begin{array}{l}\text { Ngwedo } \\
(n=29)\end{array}$ & $\begin{array}{l}\text { Overall } \\
(\mathrm{N}= \\
157)\end{array}$ & \\
\hline Bush burning/ clearing & 4.5 & 5.9 & 15.4 & 6.9 & 13.8 & 8.9 & $<.001^{\star *}$ \\
\hline $\begin{array}{l}\text { Insecticide treated cattle } \\
\text { (ITC) }\end{array}$ & 59.1 & 74.5 & 11.5 & 75.9 & 55.2 & 58.6 & \\
\hline $\begin{array}{l}\text { Not grazing in areas } \\
\text { infested with tsetse }\end{array}$ & 36.4 & 9.8 & 65.4 & 13.8 & 17.2 & 24.8 & \\
\hline $\begin{array}{l}\text { Trypano-tolerant cattle } \\
\text { breeds }\end{array}$ & 0 & 3.9 & 7.7 & 3.4 & 3.4 & 3.8 & \\
\hline $\begin{array}{l}\text { Insecticide impregnated } \\
\text { traps/ targets }\end{array}$ & 0 & 5.9 & 0 & 0 & 10.3 & 3.8 & \\
\hline
\end{tabular}

Table 7

Treatment methods of suspected cattle infected with trypanosomosis

\begin{tabular}{|c|c|c|c|c|c|c|c|}
\hline \multirow{2}{*}{$\begin{array}{l}\text { Variable } \\
\text { Treatment }\end{array}$} & \multicolumn{6}{|c|}{ Sub counties } & \multirow{2}{*}{$\begin{array}{l}x^{2} \text { value (P } \\
\text { value) }\end{array}$} \\
\hline & $\begin{array}{l}\text { Biiso } \\
(n= \\
22)\end{array}$ & $\begin{array}{l}\text { Buliisa } \\
(n= \\
51)\end{array}$ & $\begin{array}{l}\text { Butiaba } \\
(n=26)\end{array}$ & $\begin{array}{l}\text { Kigwera } \\
(n=29)\end{array}$ & $\begin{array}{l}\text { Ngwedo } \\
(n=29)\end{array}$ & $\begin{array}{l}\text { Overall }(\mathrm{N} \\
=157)\end{array}$ & \\
\hline No treatment & 0 & 2 & 7.7 & 0 & 6.9 & 3.2 & $0.023^{*}$ \\
\hline Local herbs & 0 & 3.9 & 15.4 & 20.7 & 0 & 7.6 & \\
\hline $\begin{array}{l}\text { Curative } \\
\text { trypanocides }\end{array}$ & 72.7 & 72.5 & 57.7 & 65.5 & 72.4 & 68.8 & \\
\hline $\begin{array}{l}\text { Preventive } \\
\text { trypanocides }\end{array}$ & 13.6 & 21.6 & 11.5 & 13.8 & 13.8 & 15.9 & \\
\hline $\begin{array}{l}\text { Use of } \\
\text { Veterinarians }\end{array}$ & 13.6 & 0 & 7.7 & 0 & 6.9 & 4.5 & \\
\hline
\end{tabular}


Communities' information source before administering treatment

Table 8

Communities' information source before administering treatment

\begin{tabular}{|c|c|c|c|c|c|c|c|}
\hline Variable & Sub c & unties & & & & & $\begin{array}{l}x^{2} \\
\text { value } \\
(P \\
\text { value })\end{array}$ \\
\hline $\begin{array}{l}\text { Information before } \\
\text { treatment }\end{array}$ & $\begin{array}{l}\text { Biiso } \\
(n= \\
22)\end{array}$ & $\begin{array}{l}\text { Buliisa } \\
(n= \\
51)\end{array}$ & $\begin{array}{l}\text { Butiaba } \\
(n=26)\end{array}$ & $\begin{array}{l}\text { Kigwera } \\
(n=29)\end{array}$ & $\begin{array}{l}\text { Ngwedo } \\
(n=29)\end{array}$ & Overall & \\
\hline $\begin{array}{l}\text { Farmers observation of } \\
\text { clinical signs }\end{array}$ & 77.3 & 92.2 & 57.7 & 58.6 & 82.8 & 76.4 & $0.001^{* *}$ \\
\hline Blood diagnosis & 13.6 & 2 & 11.5 & 6.9 & 3.4 & 6.4 & \\
\hline $\begin{array}{l}\text { Veterinarians observation } \\
\text { of clinical signs }\end{array}$ & 4.5 & 0 & 30.8 & 31 & 13.8 & 14 & \\
\hline $\begin{array}{l}\text { Tsetse flies on animal's } \\
\text { body }\end{array}$ & 4.5 & 5.9 & 0 & 3.4 & 0 & 3.2 & \\
\hline
\end{tabular}

Communities' practices on control of tsetse flies (Tables 9 and 10)

Bush clearing

Table 9

Participants practicing bush clearing

\begin{tabular}{|c|c|c|c|c|c|c|c|}
\hline \multirow{2}{*}{$\begin{array}{l}\text { Variable } \\
\begin{array}{l}\text { Bush } \\
\text { clearing }\end{array}\end{array}$} & \multicolumn{6}{|c|}{ Sub counties } & \multirow{2}{*}{$\begin{array}{l}x^{2} \text { value ( } P \\
\text { value) }\end{array}$} \\
\hline & $\begin{array}{l}\text { Biiso } \\
(n= \\
17)\end{array}$ & $\begin{array}{l}\text { Buliisa } \\
(n= \\
21)\end{array}$ & $\begin{array}{l}\text { Butiaba } \\
(n=17)\end{array}$ & $\begin{array}{l}\text { Kigwera } \\
(n=22)\end{array}$ & $\begin{array}{l}\text { Ngwedo } \\
(n=20)\end{array}$ & $\begin{array}{l}\text { Overall }(\mathrm{N}= \\
97)\end{array}$ & \\
\hline No & 94.1 & 85.7 & 64.7 & 100 & 70 & 83.5 & $0.012^{*}$ \\
\hline Yes & 5.9 & 14.3 & 35.3 & 0 & 30 & 16.5 & \\
\hline
\end{tabular}

Insecticide impregnated traps and targets 
Table 10

Participants using insecticide impregnated traps and targets

\begin{tabular}{|c|c|c|c|c|c|c|c|}
\hline Variable & Sub c & unties & & & & & \\
\hline $\begin{array}{l}\text { Insecticide impregnated } \\
\text { traps/targets }\end{array}$ & $\begin{array}{l}\text { Biiso } \\
(n= \\
18)\end{array}$ & $\begin{array}{l}\text { Buliisa } \\
(n= \\
43)\end{array}$ & $\begin{array}{l}\text { Butiaba } \\
(n=14)\end{array}$ & $\begin{array}{l}\text { Kigwera } \\
(n=24)\end{array}$ & $\begin{array}{l}\text { Ngwedo } \\
(n=22)\end{array}$ & $\begin{array}{l}\text { Overall } \\
(\mathrm{N}= \\
121)\end{array}$ & \\
\hline No & 94.4 & 100 & 85.7 & 100 & 77.3 & 93.4 & $0.004^{\star x}$ \\
\hline Yes & 5.6 & 0 & 14.3 & 0 & 22.7 & 6.6 & \\
\hline
\end{tabular}

During focus group discussion and key informant interviews, factors reported that contributed to the emergency of trypanosomosis were tsetse flies biting their animals, grazing animals near or inside the game reserve and grazing their animals near forested areas. During wet seasons farmers reported an upsurge of tsetse fly population compared to the dry season. Farmers reported that bigger ruminants were more susceptible to tsetse bites compared to small ruminants like goats and sheep. According to farmer, the clinical signs of bovine trypanosomosis exhibited included loss of appetite, emaciation, intermittent fevers, eyes producing tears and in calves the disease may cause death if not treated. The most common drugs used in treating suspected infected animals were Samorin (Isometamidium Chloride) and Berenil (Diminazene Aceturate). The most common practices used in herds was spraying animals using insecticide. The use of insecticide impregnated traps and targets in controlling the vector was not commonly used as a control strategy. During the discussion and interviews human cases of trypanosomosis were mentioned as a health challenge in Buliisa district.

\section{Discussion}

KAP studies are vital in identifying knowledge gaps, cultural beliefs and behavior patterns that may categorize needs, problems and barriers to help plan and implement interventions in communities. The results from such studies propose intervention strategy that reflect specific local circumstances, the underlying cultural beliefs that influence them, plan activities that are suited to the respective population.

From our study it is clearly evident that majority of farmers in Buliisa district (96.8\%) had ever seen tsetse flies and about (91.7\%) had ever heard about bovine trypanosomosis into their area with no significant difference $(P=0.610)$ among the study sub counties. These revelations indicated the magnitude of bovine trypanosomosis burden was a major constraint within the pastoral communities around MFNP to cattle productivity. The high proportions of study participants who had ever seen tsetse and had ever heard about bovine trypanosomosis were similar to findings of from a study from Eastern Uganda by 
(Magona et al., 2004) in Tororo and Busia. The location of Buliisa in the cattle corridor, vegetation type, bordering a national park and water body and hosting a wildlife reserve are plausible reasons for the presence of tsetse flies which enhance trypanosomosis being a major cattle disease in this area. Wild animals especially wild ruminants, elephants and wild suids act as maintenance hosts of Glossina species, the anthropod vector that transmit trypanosomosis (Bengis et al., 2002) which accentuates the population of tsetse flies. Seasonal changes influence the living conditions of different tsetse fly species. The Palpalis and Fusca tsetse fly species survive well in moist conditions surrounded by woody vegetation while the moristan species thrive well in hot, dry conditions and during wet season they migrate into savanna woodland. In the dry season moristan species the live in vegetation near water bodies. Furthermore, seasonal change modifies the relative humidity, vegetation, temperature, light radiance which influence the development and multiplication of the tsetse flies.(Sow, 2013). Farmers grazing near the national parks $(60.5 \%)$ and animals sharing grazing land and watering points $(19.1 \%)$ were reported as the main causes of bovine trypanosomosis in Buliisa district. Contrary to this finding, a study in Kenya (Machila et al., 2003) found that $44.1 \%$ of the respondents reported that tsetse flies were the main cause of trypanosomosis and $54 \%$ of the respondents did not know the cause of trypanosomosis

There was highly significant difference in knowledge about the causes of trypanosomosis $(P=0.004)$ across the study sub counties. The difference can be attributed to the difference in persistence and magnitude of prevalence of the disease in different geographical locations and proximity to the national park. In geographical locations close to national parks, farmers can easily associated prevalence of trypanosomosis to grazing animals near national parks. (Mechtilda et al., 2016). The responses on the causes of trypanosomosis suggested by the participants are in agreement with the acceptable scientific cause of the disease. This finding suggests that farmers in Buliisa district seem to be highly knowledgeable about the causes and risk factors of trypanosomosis which enables the pastoral communities and their cattle herds to be resilient and survive in that environment. A study in Nwoya, a district neighboring the same high risk protected area found a prevalence rate of $41 \%$ (Angwech et al., 2015) which is likely to be the same case in Buliisa district. It is therefore necessary to determine the prevalence of bovine trypanosomosis and evaluate if the high knowledge of cattle farmers in Bullisa district on the scientific cause of trypanosomosis can be attributed to the disease prevalence.

The participants' knowledge on how trypanosomosis is transmitted in their herds ranged from animals being fed on by tsetse flies (31.2\%), animals grazing in areas infested with tsetse flies (30.6\%) to animals being fed on by tsetse flies carrying the pathogen (29.9\%) in proportionate proportions. There is almost equal proportion of the participants who are able to tell the difference between transmission of trypanosomosis by only tsetse bites and by tsetse flies bites carrying the disease pathogens. Knowledge on transmission of trypanosomosis differed highly significantly $(P=0.003)$ among the study sub counties where all stated transmission routes are scientifically correct. Such results reflect the level of accuracy of some livestock farmers in the study area in correctly knowing how the disease in transmitted in their herds. This finding is contrary to a study in Ethiopia by (Chanie et al., 2013) that revealed $80 \%$ of the respondents thought bovine trypanosomosis was caused and transmitted via the environment. 
The major signs of trypanosomosis identified by farmers differed significantly $(P=0.001)$ across the study counties. The clinical signs identified by the farmers focused mainly on the impaired animals' physiological processes and not on economic losses. Participants however did not link the signs of trypanosomosis to loss in milk production, mortality and other productivity indicators like decreased offtake and reduced calving rate as reported in several studies (Swallow, 2000) (Muhanguzi et al., 2014). The reason for lack of connection between productivity indices and the clinical signs may be attributed to the multiple functions of cattle in pastoral communities which are beyond production of milk and beef. The highly significant difference among the sub counties in interpreting disease signs could be attributed to the fact that farmers could at least associate one peculiar sign to presence of the disease in their herds.

The ability and precision to identify these visual signs depend on the experience of the farmers. Although there are other diseases that can present similar signs like trypanosomosis but with long periods of practice, farmers have developed comparable understanding of the important signs of the disease in their herds. (Ayenalem et al., 2017). The correct knowledge of pastoral communities on the signs and symptoms of trypanosomosis could also have contributed to some farmers starting to crossbreed their local indigenous cattle and keeping high productive and highly susceptible crossbred cattle

The control practices of trypanosomosis carried out focused mainly on control tsetse flies getting into contact with animals and highly significantly differed $(P=0.001)$ the study sub counties. The control practices that target controlling the tsetse flies in their habitat (bush clearing and traps) were less practiced by the farmers. There are several control strategies of the trypanosomosis in Uganda including strategies targeting the disease vector, stationary baits, mobile baits (insecticide treated cattle) and aerial spraying. The success of these strategies, their technical efficiency and the affordability by the farmers is at different stages at both farm and community level. (Muhanguzi et al., 2015). Farmers in choosing from the available control options are driven by the cost and usually the insecticide treated cattle option seems widely used in Uganda (Waiswa \& Wangoola, 2018) and cheapest as stated in a study by (Shaw et al., 2013) who costed tsetse control options per KM $\mathrm{KM}^{2}$ as US\$ 285 using traps, US\$ 30 using insecticide treated cattle, US\$380 using sequential aerial technique and US\$758 using sterile insect technique. The insecticide treated cattle strategy is a widely used approach by farmers probably because of the dual benefits of controlling tsetse and ticks, the vectors for trypanosomosis and tick borne diseases respectively. These findings are in contrast from a study in Tanzania by (Mwaseba \& Kigoda, 2017b) which found that dipping was the major control method of trypanosomosis. Avoiding grazing cattle in risky areas can be rather a challenging strategy in pastoral setting especially where the land tenure system is communal. In the dry spell, pastures and watering points are limited thereby forcing herders to graze and water their animals in the same location shared by wildlife. During dry season tsetse flies especially the moristans species live in vegetation close to water points targeting both domestic and wild ruminants for blood meals (Hargrove, 2004).

A small proportion of cattle farmers (6.6\%) reported using insecticide impregnated traps and targets and bush clearing (16.5\%) as control practices of the tsetse vector. The tsetse population changes in time and 
space therefore cannot not effectively be monitored and disease management strategy based on tsetse population is difficult to implement.

The over dependence of farmers on using insecticide treated cattle as a major control strategy of bovine trypanosomosis could be attributable to a breakdown of the livestock extension and entomology community intervention programs that control the vector (tsetse) population that transmits the disease.

The most common treatment method of trypanosomosis is using curative trypanocides $(68.8 \%)$ and followed by use of preventive trypanocides $(15.9 \%)$ with a significant difference $(P=0.023)$ across the study sub counties Although both curative and prophylactic trypanocides are effective in treating and controlling trypanosomosis respectively, the choice to use curative trypanocides to treat suspected infected cattle can be attributed to the fact that fatality cases from trypanosomosis are not immediate. In addition, using prophylactic trypanocides can be expensive to the farmers since it involves treating the entire average herd of about 34 animals. Treating only suspected sick animals that have shown signs of the disease is a cheaper option in the shorter term for farmers.

The farmers' decision to administer treatment to their cattle was based on observation of clinical signs. A highly significant difference $(P=0.001)$ was observed among the study sub counties on information based on before administering treatment. The difference could be a result of the years of experience in cattle keeping and herd sizes. In smaller herd sizes farmers can easily use clinical signs correctly compared to in larger herd sizes. The longer the experience in cattle keeping the higher the chances to use clinical signs correctly as these are among the many factors that can contribute to control or persistence of animal trypanosomosis in a community as evidenced by (Wangoola et al., 2019) in a recent study covering Lango sub region of Uganda. The practice of using clinical signs before treatment further suggests that many seemingly healthy animals are left untreated. Without proper diagnosis of animals, it may result in treating wrong disease condition since there are other diseases that can present similar signs like bovine trypanosomosis such as East Coast Fever and Helminthiasis. The use of clinical signs may be attributed to lack of animal diagnostic facilities leading to failure in getting results in real time by farmers, the costs and expertise involved in collecting the blood samples from the animals and the long distances from the study area to places where laboratory services can be found. In addition, although rapid diagnostic tool (Very-Diag manufactured by Ceva Sante Animale Libourne France) is available, the tool is still not widely used by livestock farmers probably due to cost or unavailability of the technology in the study area. The practice of administering treatment of cattle against trypanosomosis without proper diagnosis can lead to misuse and abuse of trypanocides and cause resistance of trypanosome against the drug.

\section{Conclusion}

The majority of the participants were highly knowledgeable on the disease vector, the clinical signs, predisposing factors, and disease control measures. The attitude of participants about trypanosomosis was very positive with the majority had heard or seen tsetse, heard about Nagana and considered Nagana an 
important disease in the study sub counties. The control practices identified were spraying using insecticides and avoiding grazing their animals in areas infested with tsetse flies.

\section{Declarations}

\section{Ethics approval and consent to participate:}

the study protocol was approved by Makerere University School of Veterinary Medicine Animal Resources (SVAR) higher degrees, SVAR research and ethics committees (SVAREC /19/2018). Study participants signed a voluntary consent to participate in the study.

\section{Availability of data and materials:}

The dataset(s) supporting the conclusions of this article is (are) available from the corresponding author on reasonable request

\section{Consent for publication:}

All the authors have approved the manuscript for submission.

\section{Competing interests:}

The authors report no conflict of interest.

\section{Funding:}

Acknowledgement to the Government of Uganda support, Uganda Trypanosomiasis Control Council (UTCC) through the Coordinating Office for the Control of Trypanosomosis in Uganda (COCTU) and World Bank supported African Centre of Excellence in Agro ecology and livelihood Systems (ACALISE) for funding this study.

\section{References}

1. Albert, M., Wardrop, N. A., Atkinson, P. M., Torr, S. J., \& Welburn, S. C. (2015). Tsetse Fly (G.f. fuscipes) Distribution in the Lake Victoria Basin of Uganda. PLoS Neglected Tropical Diseases, 9(4), 1-14. https://doi.org/10.1371/journal.pntd.0003705

2. Angwech, H., Nyeko, J. H. P., Opiyo, E. A., Okello-Onen, J., Opiro, R., Echodu, R., Malinga, G. M., Njahira, M. N., \& Skilton, R. A. (2015). Heterogeneity in the prevalence and intensity of bovine trypanosomiasis in the districts of Amuru and Nwoya, Northern Uganda. BMC Veterinary Research, 11(1), 1-8. https://doi.org/10.1186/s12917-015-0567-6

3. Ayenalem, D., Mossie, T., \& Ababa, A. (2017). Prevalence of Bovine Trypanosomosis and Farmers ' Perception of the Disease and Its Management in Guangua and Dangila Districts. 7(7), 1-10. 
4. Bengis, R. G., Kock, R. A., \& Fischer, J. (2002). Infectious animal diseases: the wildlife/livestock interface. Revue Scientifique et Technique (International Office of Epizootics), 21(1), 53-65.

5. Chanie, M., Adula, D., \& Bogale, B. (2013). Socio-Economic Assessment of the Impacts of Trypanosomiasis on Cattle in Girja District, Southern Oromia Region, Southern Ethiopia. Acta Parasitologica Globalis, 4(3), 80-85. https://doi.org/10.5829/idosi.apg.2013.4.3.7523

6. Cox, A. P., Tosas, O., Tilley, A., Picozzi, K., Coleman, P., Hide, G., \& Welburn, S. C. (2010). Constraints to estimating the prevalence of trypanosome infections in East African zebu cattle. Parasites and Vectors, 3(1), 1-8. https://doi.org/10.1186/1756-3305-3-82

7. Hargrove, J. W. (2004). Tsetse population dynamics. In I. P. H. H. and M. A. M. Maudlin (Ed.), The Trypanosomiases. CABI Publishing.

8. Holt, H. R., Selby, R., Mumba, C., Napier, G. B., \& Guitian, J. (2016). Assessment of animal African trypanosomiasis (AAT) vulnerability in cattle-owning communities of sub-Saharan Africa. Parasites \& Vectors, 9(1), 53. https://doi.org/10.1186/s13071-016-1336-5

9. Kristjanson, P., Swallow, B., Rowlands, G., Kruska, R., \& DeLeeuw, P. (1999). No TitleMeasuring the costs of aafrican Animal Trypanosomaisis: the potential benefits of control and returns to research. The Agricultire Sysytems, 59, 79-98. https://doi.org/10.1016/S0308-521X(98)00086-9

10. Machila, N., Wanyangu, S. W., McDermott, J., Welburn, S. C., Maudlin, I., \& Eisler, M. C. (2003). Cattle owners' perceptions of African bovine trypanosomiasis and its control in Busia and Kwale Districts of Kenya. Acta Tropica, 86(1), 25-34. https://doi.org/10.1016/S0001-706X(02)00288-7

11. Magona, J. W., Walubengo, J., \& Olaho-Mukani, W. (2004). Knowlege and attitudes of cattle owners regarding trypanosomosis control in tsetse-infested areas of Uganda. Journal of the South African Veterinary Association, 75(4), 173-176. https://doi.org/10.4102/jsava.v75i4.478

12. Malulu, D. J., Kimbita, E. N., Tuntufye, H. N., Kinung'hi, S., Nyingilili, H. S., Lyaruu, E., Mbilu, T., Sahani, J. K., \& Malele, I. I. (2017). Assessment of community knowledge, attitude and practices for sustainable control of tsetse and tsetse-borne trypanosomosis in meatu district, TanzaniaMalulu, D. J., Kimbita, E. N., Tuntufye, H. N., Kinung'hi, S., Nyingilili, H. S., Lyaruu, E., ... Malele, . Livestock Research for Rural Development, 29(5). http://www.Irrd.org/Irrd29/5/malu29096.html

13. Mechtilda, B., Gamba, N., \& Sebastian, M. (2016). Evaluation of knowledge, attitude and practices of agro-pastoralists on tsetse fly (Glossina sp.) in Western Serengeti Tanzania. Journal of Veterinary Medicine and Animal Health, 8(11), 169-175. https://doi.org/10.5897/JVMAH2016.0496

14. Muhanguzi, D., Okello, W. O., Kabasa, J. D., Waiswa, C., Welburn, S. C., \& Shaw, A. P. M. (2015). Cost analysis of options for management of African Animal Trypanosomiasis using interventions targeted at cattle in Tororo District; South-eastern Uganda. Parasites and Vectors, 8(1), 1-9. https://doi.org/10.1186/s13071-015-0998-8

15. Muhanguzi, D., Picozzi, K., Hattendorf, J., Thrusfield, M., Kabasa, J. D., Waiswa, C., \& Welburn, S. C. (2014). The burden and spatial distribution of bovine African trypanosomes in small holder croplivestock production systems in Tororo District, south-eastern Uganda. Parasites and Vectors, 7(1), 1-10. https://doi.org/10.1186/s13071-014-0603-6

Page $17 / 19$ 
16. Mwaseba, D. L., \& Kigoda, K. J. (2017a). Knowledge, attitude, and practices about tsetse control among communities neighbouring Serengeti National Park, Tanzania. Heliyon, 3(6), e00324. https://doi.org/10.1016/j.heliyon.2017.e00324

17. Mwaseba, D. L., \& Kigoda, K. J. (2017b). Knowledge, attitude, and practices about tsetse control among communities neighbouring Serengeti National Park, Tanzania. Heliyon, 3(6). https://doi.org/10.1016/J.HELIYON.2017.E00324

18. Shaw, A. P. M., Torr, S. J., Waiswa, C., Cecchi, G., Wint, G. R. W., Mattioli, R. C., \& Robinson, T. P. (2013). Estimating the costs of tsetse control options: An example for Uganda. Preventive Veterinary Medicine, 110(3-4), 290-303. https://doi.org/10.1016/j.prevetmed.2012.12.014

19. Sow, A. (2013). Trypanosomosis risk factors and impact assessment of a tsetse and trypanosomosis eradication campaign in Burkina Faso. 165.

20. Swallow, B. M. (2000). Impact of trypanosomiasis on African agriculture. PAAT Technical and Scientific Series 2. FAO (Food and Agriculture Organization of the United Nations),.

21. Van den Bossche, P., Rocque, S. de La, Hendrickx, G., \& Bouyer, J. (2010). A changing environment and the epidemiology of tsetse-transmitted livestock trypanosomiasis. Trends in Parasitology, 26(5), 236-243. https://doi.org/10.1016/j.pt.2010.02.010

22. Waiswa, C., \& Wangoola, M. R. (2018). Sustaining Efforts of Controlling Zoonotic Sleeping Sickness in Uganda Using Trypanocidal Treatment and Spray of Cattle with Deltamethrin. XX(Xx), 1-6. https://doi.org/10.1089/vbz.2018.2382

23. Wangoola, R. M., Kevin, B., Acup, C. A., Welburn, S., Waiswa, C., \& Bugeza, J. (2019). Factors associated with persistence of African animal trypanosomiasis in Lango subregion, northern Uganda. Tropical Animal Health and Production, 51(7), 2011-2018. https://doi.org/10.1007/s11250019-01900-7

24. WHO (Ed.). (2008). Advocacy, communication and social mobilization for TB control: a guide to developing knowledge, attitude and practice surveys.

\section{Figures}




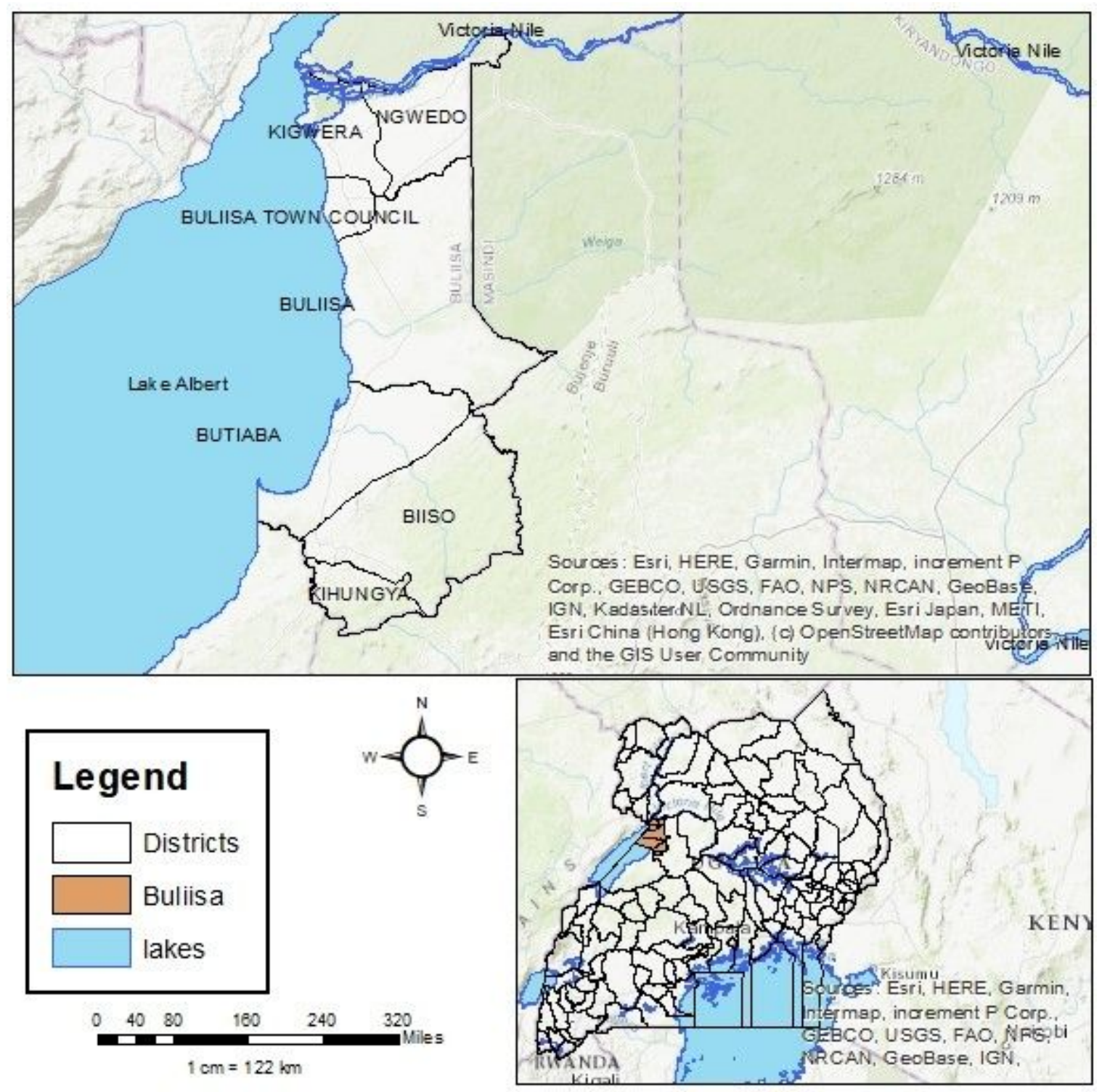

Figure 1

Map of Uganda showing the study district. Note: The designations employed and the presentation of the material on this map do not imply the expression of any opinion whatsoever on the part of Research Square concerning the legal status of any country, territory, city or area or of its authorities, or concerning the delimitation of its frontiers or boundaries. This map has been provided by the authors. 